\title{
Aspecte epidemiologice şi clinicoevolutive ale infecției cu SARS-CoV-2 - o analiză intermediară a cazurilor din Spitalul Clinic „Victor Babeş“, Craiova, România
}

\author{
Florentina Dumitrescu ${ }^{1,2}$, Adina Andreea Turcu ${ }^{1,2}$, Livia Dragonu ${ }^{1,2}$, \\ Andreea-Cristina Stoian ${ }^{1}$, Iulian Diaconescu ${ }^{1,2}$, Radu Diaconu ${ }^{1,3}$, Lucian Giubelan ${ }^{1,2}$ \\ ${ }^{1}$ Universitatea de Medicină şi Farmacie, Craiova, România \\ 2Spitalul Clinic de Boli Infecţioase şi Pneumoftiziologie „Victor Babeş“, Craiova, România \\ ${ }^{3}$ Spitalul Clinic Filantropia, Craiova, România
}

\begin{abstract}
REZUMAT
Obiective. Raportarea experienţei Spitalului Clinic „Victor Babeş“ din Craiova, România, privind aspectele epidemiologice şi clinico-evolutive ale infecţiei cu SARS-CoV-2.

Material şi metode. Studiu retrospectiv, 01.03-31.05.2020, cu analiza datelor clinice şi paraclinice ale pacienţilor diagnosticaţi cu COVID-19.

Rezultate. 245 pacienţi spitalizaţi cu COVID-19, mediana vârstei 39 ani $(0,81), 128(52,2)$ au fost bărbaţi, $133(54,3 \%)$ au avut contact apropiat cu caz confirmat, $71(28,9 \%)$ cazuri din import. Au fost raportate trei mari focare familiale (20, 13, 9 cazuri) şi un focar colectiv (28 jandarmi); 29 cadre medicale au fost spitalizate. Cele mai frecvente simptome au fost tusea - 110 (57.9\%) şi febra - 86 (45.3\%). Au fost înregistrate 10 decese $(4,1 \%), 192$ vindecaţi $(78,4 \%), 43$ erau încă spitalizaţi la finalul studiului. Mediana duratei de spitalizare la pacienţii vindecaţi a fost de 13,5 zile $(8,35)$. Decesele s-au asociat cu vârsta înaintată şi comorbidităţi. Concluzii. La pacienţii spitalizaţi cu COVID-19 au fost identificate câteva focare importante; aspectele clinice au fost frecvent de tip infecţie respiratorie uşoară; decesele s-au asociat cu vârsta înaintată şi comorbidităţi.
\end{abstract}

Cuvinte cheie: SARS-CoV-2, COVID-19, epidemiologie

\section{INTRODUCERE}

COVID-19 (acronim derivat din coronavirus disease 2019) este denumirea bolii determinate de o tulpină nouă de coronavirus (SARS-CoV-2), cu potenţial de evoluţie spre sindrom respirator acut sever [1].

Coronavirusurile au ca gazde naturale liliecii şi au fost identificate la mai multe specii de animale (MERS-CoV la cămile, SARS-CoV-1 la pisicile civete) $[2-4]$.

SARS-CoV-2, virus ARN de origine zoonotică, a avut probabil o evoluţie adaptativă în gazed interme- diare, transferul la om fiind facilitat de asemănarea receptorilor (enzima de conversie a angiotensinei 2 ACE2), care au permis o barieră scăzută a speciilor pentru transmiterea virusului între oameni şi animale [5].

Recenta izbucnire a COVID-19 la Wuhan [6] s-a transformat într-o urgenţă de sănătate publică şi de îngrijorare internaţională, prin aspectele noi legate de provocările terapeutice, profilaxia specific şi contagiozitatea ridicată. Deoarece este un virus nou, în lipsa unei imunităţi prealabile postexpunere, întreaga po- 
pulaţie umană este potenţial susceptibilă la infecţia SARS-CoV-2.

COVID-19 a prezentat o creştere exponenţială a numărului de cazuri începând cu sfârşitul lunii februarie 2020, trecând la o transmitere comunitară susţinută, care a afectat la nivel mondial peste 180 de ţări [7]. În Europa, escaladarea rapidă a îmbolnăvirilor în ţări precum Italia şi Spania a reprezentat o provocare majoră, care a pus o presiune enormă asupra sistemului de asistenţă medicală [8].

Datele preliminare din ţările UE /SEE arată că aproximativ 30\% dintre cazurile de COVID-19 diagnosticate au fost spitalizate, înregistrând o letalitate de 12\% [8]. Estimările efectuate au arătat că riscul de îmbolnăvire, formele severe de boală şi letalitatea sunt mai mari pentru persoanele în vârstă de peste 60 ani şi cele cu comorbidităţi (de exemplu, hipertensiune arterială, diabet, boli cardiovasculare, boli respiratorii cronice şi neoplazice) [9]. S-a observat că bărbaţii au fost afectaţi în procent mai ridicat decât femeile, iar copiii au un risc mai redus decât adulţii de a dezvolta simptome sau forme severe, constituind o proporţie mică (sub 5\%) din totalul cazurilor COVID-19 raportate [8].

Abordările de testare prin RT-PCR (reverse transcription polymerase chain reaction) sunt adaptate situaţiei la nivel naţional şi local, fiind stabilite ca prioritare anumite categorii de pacienţi.

Simptomele COVID-19 variază în severitate, Wu şi McGoogan raportând pe cazuistica studiată $81 \%$ forme asimptomatice sau uşoare, $14 \%$ severe (hipoxie, dispnee, extinderea afectării pulmonare $>50 \%$ în $24-48$ de ore), $5 \%$ critice (şoc, insuficienţă respiratorie, disfuncţie multiorganică), iar 2,3\% fatale [10]. Rapoartele arată că deteriorarea clinică poate apărea rapid, cel mai frecvent în a doua săptămână de boală [8].

În România, conform datelor Institutului Naţional de Sănătate Publică, până la data de 31.05.2020, au fost confirmate 19.257 cazuri COVID-19, cu 1.262 decese (fatalitate 6,5\%). Pacienţii decedaţi au prezentat cel puţin o comorbiditate $(90,7 \%), 76,4 \%$ fiind persoane peste 60 ani, iar 58,7\% bărbaţi [11]. Judeţul Dolj a înregistrat 223 cazuri, cu o incidenţă sub 10/100.000 locuitori, mai redusă comparativ cu alte zone ale ţării [12].

\section{OBIECTIVE}

$\mathrm{Ne}$-am propus evaluarea aspectelor epidemioloice şi clinico-evolutive ale cazurilor de COVID-19, spita- lizate la Spitalul Clinic de Boli Infecţioase şi Pneumoftiziologie „Victor Babeş“ din Craiova, România.

\section{MATERIAL ŞI METODE}

Am realizat un studiu retrospectiv, cu analiza datelor consemnate în documentele medicale pentru pacienţii spitalizaţi cu COVID-19, în perioada 01.03.202031.05.2020. Au fost evaluate datele demografice, epidemiologice, datele clinice, parametrii biologici şi rezultatele investigaţiilor şi consulturilor paraclinice. Confirmarea infecţiei cu SARS- CoV-2 s-a efectuat prin RT-PCR din exsudatul nazo-faringian, iar externarea pacienţilor vindecaţi s-a efectuat după obţinerea a două rezultate RT-PCR SARS-CoV-2 consecutive negative (recoltate la interval de minimum 24 de ore). Am utilizat testul Fisher pentru a stabili corelaţia dintre diferiţi parametri, valoarea $\mathrm{p} \leq 0,05$ fiind considerată semnificativă statistic.

\section{REZULTATE}

Lotul studiat a cuprins 245 de pacienţi spitalizaţi cu COVID-19, în perioada 01.03-31.05.2020, la Spitalul Clinic de Boli Infecţioase şi Pneumoftiziologie „Victor Babeş“ din Craiova. Cele mai multe cazuri au fost internate în săptămâna 24-30 aprilie 2020 (Figura 1).

Caracteristicile pacienţilor sunt prezentate în Tabelul 1. Mediana vârstei a fost de 39 ani, sexul masculin a fost mai afectat (raport bărbaţi/femei $=1,09$ ) şi au predominat cazurile din mediul urban (raport urban/rural $=2,6$ ).

TABEL 1. Caracteristicile pacienților cu COVID-19

\begin{tabular}{|l|c|c|}
\hline & Număr & Pocent \\
\hline Vârsta, mediana (IQR) ani & $39(0,81)$ & \\
\hline Sex, masculin & 128 & 52,2 \\
\hline Mediul de provenienţă, urban & 177 & 72,2 \\
\hline Cazuri din import & 71 & 28,9 \\
\hline Contact cu caz con t!? & 133 & 54,3 \\
\hline Personal sanitar & 29 & 11,8 \\
\hline $\begin{array}{l}\text { Durata de la debut până la } \\
\text { internare, mediana (IQR) zile }\end{array}$ & $4(0,12)$ & \\
\hline Formă severă & 28 & 11,4 \\
\hline
\end{tabular}

Copiii au reprezentat 9,8\% dintre cazuri (au fost spitalizaţi 3 sugari, în vârstă de 3, 4 şi 8 luni) şi s-au înregistrat 39 pacienţi $(15,9 \%)$ cu vârsta peste 60 ani (figura 2); au fost înregistrate 3 cazuri la gravide.

$\mathrm{Au}$ fost spitalizaţi 213 pacienţi din judeţul Dolj şi 23 din judeţele limitrofe (10 - Olt, 6 -Gorj, 11 - Me- 


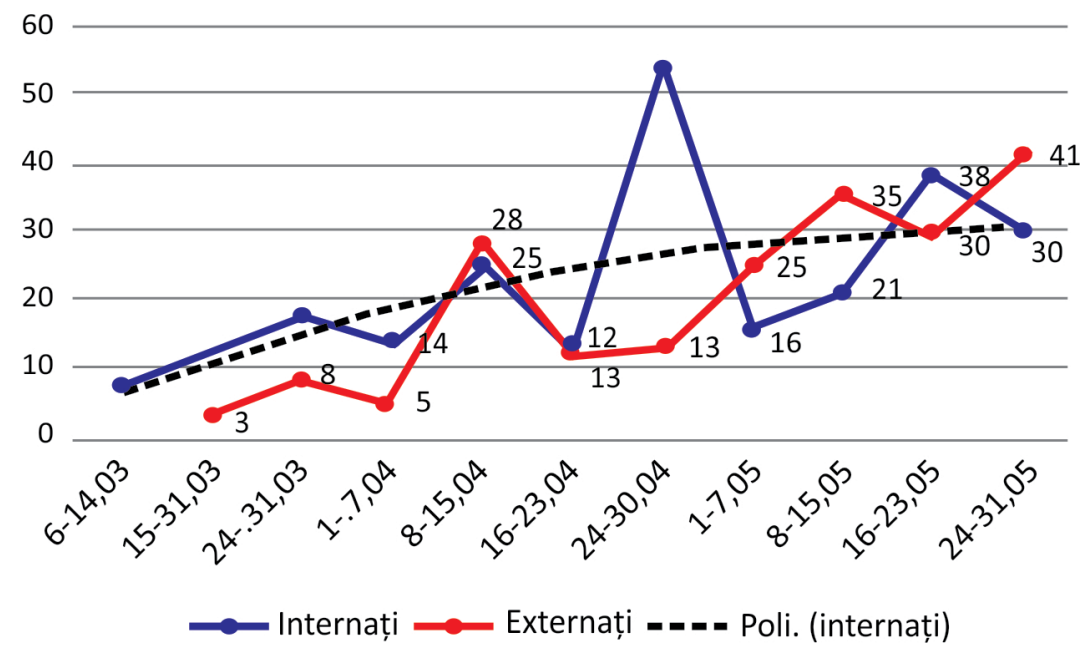

FIGURA 1. Repartiția numerică săptămânală a cazurilor

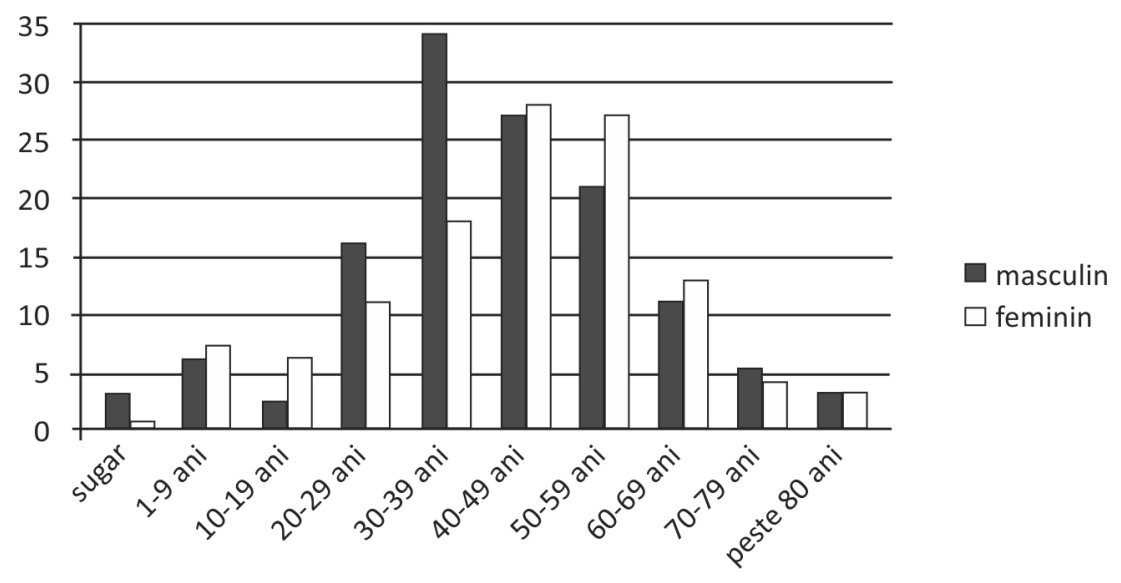

FIGURA 2. Repartiția numerică a cazurilor pe grupe de vârste şi sex

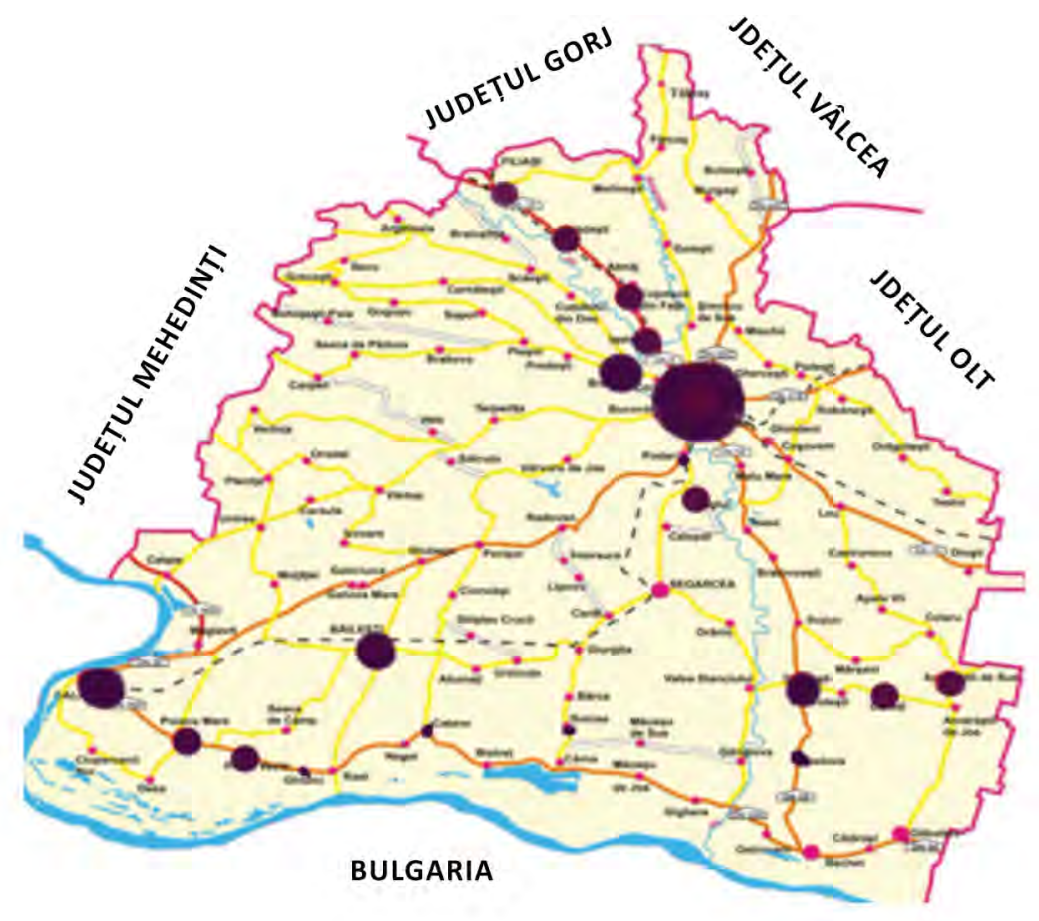

FIGURA 3. Distribuția cazurilor din județul Dolj 
hedinţi, 5- Vâlcea); numărul cel mai mare de pacienţi din judetul Dolj a fost înregistrat în zona urbană Craiova -137 cazuri (Figura 3 ).

Link-ul epidemiologic a orientat în diagnosticarea cazurilor, 133 pacienţi $(54,3 \%)$ prezentând contact cu caz confirmat. Cazurile de import au reprezentat $28,9 \%$ din lot, cele mai multe fiind asociate cu istoric recent de călătorie în Italia (28), Anglia (22), Spania (5). Au fost identificate 3 focare familiale cu număr mare de cazuri - 20,13, respectiv 9 persoane - şi un focar colectiv - 28 jandarmi; s-au înregistrat 29 cazuri $(11,8 \%)$ la cadre medicale ( 2 medici, 19 asistente, 8 infirmiere), niciunul dintre acestea din spitalul nostru.

Cele mai frecvente comorbidităţi au fost cardiovasculare: 81 pacienţi $(33,1 \%)$-hipertensiune arterială (HTA), 43 (17,6\%)-alte suferinţe cardiovasculare, obezitatea - 44 cazuri $(17,9 \%)$ şi diabetul zaharat (DZ) - 32 pacienţi $(13,1 \%)$; s-au înregistrat 8 cazuri la pacienţi cu neoplazii.

Simptomele dominante au fost tusea - $110(57,9 \%)$ şi febra - $86(45,3 \%)$; radiografia pulmonară a evidenţiat aspect de pneumonie interstiţială sau de tip opacităţi unice /multiple în 54,5\% dintre cazuri (Tabel 2).

TABEL 2. Aspecte clinice şi radiologice la pacienții $c u$ COVID-19

\begin{tabular}{|l|c|}
\hline Manifestări clinice (190) & $\mathrm{N}(\%)$ \\
\hline Tuse & $110(57,9 \%)$ \\
\hline Febră & $86(45,3 \%)$ \\
\hline Frison & $46(24,2 \%)$ \\
\hline Dispnee & $40(21,1 \%)$ \\
\hline Disfagie & $42(22,1 \%)$ \\
\hline Rinoree & $14(7,4 \%)$ \\
\hline Dureri toracice & $11(5,8 \%)$ \\
\hline Mialgii & $28(14,7 \%)$ \\
\hline Anosmie & $27(14,2 \%)$ \\
\hline Ageuzie & $22(11,6 \%)$ \\
\hline Cefalee & $24(12,6 \%)$ \\
\hline Astenie & $15(7,9 \%)$ \\
\hline Diaree & $11(5,8 \%)$ \\
\hline Inapetenţă & $10(5,3 \%)$ \\
\hline Artralgii & $7(3,7 \%)$ \\
\hline Ameţeli & $3(1,6 \%)$ \\
\hline Aspect radiologic (178) & $81(45,5 \%)$ \\
\hline Normal & $44(24,7 \%)$ \\
\hline Pnumonie inters & $53(29,7 \%)$ \\
\hline Opacită & \multicolumn{2}{|l}{} \\
\hline
\end{tabular}

Au primit medicaţie cu acţiune antivirală 176 pacienţi (71,8\%): 70 cazuri -lopinavir/ritonavir (LPV/r)+ hidroxiclorochină (HCQ), 53 cazuri - LPV/r, 50 ca- zuri- HCQ, 3 cazuri - HCQ+darunavir/cobicistat; 6 pacienţi au fost trataţi şi cu tocilizumab, 18 cazuri au necesitat corticoterapie.

Au predominat formele uşoare de boală -117 cazuri (47,8\%), formele medii (45 cazuri) si severe (28 cazuri) fiind înregistrate în $18,4 \%$, respectiv $11,4 \%$ dintre cazuri; 55 de pacienţi $(22,4 \%)$ au fost asimptomatici. Copiii au prezentat forme uşoare de boală, formele severe fiind întâlnite la pacienţi vârstnici, cu comorbidităţi. Au necesitat internare în terapie intensivă 31 de pacienţi, 10 fiind intubaţi orotraheal şi ventilaţi mecanic; supliment de oxigen pe mască sau ventilaţie mecanică noninvazivă au necesitat alţi 25 de pacienţi.

La finalul perioadei de studiu, erau externaţi 202 pacienţi: 192 vindecaţi $(78,4 \%), 10$ decese $(4,1 \%) ; 43$ de pacienţi erau încă spitalizaţi. Durata de spitalizare pentru cazurile vindecate a fost de 13,5 zile (IQR 8, 35 ), cu o mediană de 12 zile (IQR 8,23 ) pentru cazurile asimptomatice, 15 zile (IQR 8, 35) pentru cazurile uşoare, 15 zile (IQR 8,29) pentru cazurile medii şi 19,5 zile (IQR 9, 26) pentru cazurile severe.

Decesele au fost asociate cu vârsta peste 60 de ani $(\mathrm{p}<0,0001)$, HTA $(\mathrm{p}=0,01)$ şi DZ $(\mathrm{p}=0,002)$.

\section{DISCUȚII}

Primul caz confirmat cu COVID-19 în România a fost raportat pe 26 februarie 2020, iar pe 16 martie 2020 a fost declarată stare de urgenţă [13], persoanele care se întorceau din zone de risc urmând izolarea la domiciliu sau carantinarea instituţionalizată. Conform datelor Institutului Naţional de Sănătate Publică, până la data de 31.05.2020 erau confirmate 19.257 cazuri COVID-19 [12], cu o mediană a vârstei de 48 ani (IQR 0,99), lotul nostru având o mediană mai scăzută a vârstei - 39 ani (IQR 0, 81). Au fost înregistrate $28,9 \%$ cazuri de import, persoane care s-au întors din ţări cu număr mare de cazuri de COVID-19 (Italia, Anglia, Spania), un procent mult mai mare comparativ cu cel înregistrat la nivelul ţării -3,3\%. Personalul sanitar confirmat cu COVID-19 din lotul studiat a constituit $11,8 \%$ dintre cazuri, similar cu procentul înregistrat pe întreg teritoriul României $(14,8 \%)$. Cea mai frecventă comorbiditate prezentă la pacienţii cu COVID-19 a fost HTA (33,1\%), iar DZ a fost întâlnit la $13,1 \%$ dintre cazuri, date similare cu cele comunicate în alte studii $[14,15]$.

Cele mai frecvente simptome au fost tusea $(57,9 \%)$ şi febra $(45,3 \%)$, dar în procente mult mai reduse faţă 
de cele din în alte studii, care raportau febra la peste $76 \%$ şi tusea la peste $59 \%$ dintre cazuri [14-18]. Au fost raportate, în schimb, anosmia $(14,2 \%)$ şi ageuzia $(11,6 \%)$, în procente asemănătoare cu cele dintr-un studiu desfăşurat la un spital din Milano [19]. Disfagia a fost prezentă la $22,1 \%$ dintre pacienţi, procente ceva mai reduse $(17,4 \%, 13,9 \%)$ fiind raportate şi de alţi autori $[14,16]$. Cele mai multe cazuri au fost uşoare şi medii, cazurile severe fiind înregistrate la $11.4 \%$ dintre cazuri, îndeosebi la pacienţi cu comorbidităţi (HTA, DZ, neoplazii), similar cu alte date publicate în literatură $[10,14,16,17]$. Rata deceselor a fost de $4,1 \%$, mai redusă comparativ cu cea înregistrată la nivelul României - 6,5\% [12], dar aproape dublă faţă de cea raportată de $\mathrm{Wu} \mathrm{Z}$ şi colab. - 2,4\% [10].

Limitele studiului sunt reprezentate de numărul relativ mic de cazuri; nu a fost analizată influenţa trata-

\section{BIBLIOGRAFIE}

1. Gorbalenya AE, Baker SC, Baric RS et al. Severe acute respiratory syndrome-related coronavirus: The species and its viruses-a statement of the Coronavirus Study Group. bioRxiv.2020:1-15.

2. Anthony S J, Gilardi K, Menachery V D et al. Further Evidence for Bats as the Evolutionary Source of Middle East Respiratory Syndrome Coronavirus. mBio. 2017;8(2):1-13.

3. Azhar El, El-Kafrawy SA, Farraj SA et al. Evidence for camel-to-human transmission of MERS coronavirus. $N$ Engl $J$ Med. 2014;370:2499-2505.

4. Li W, Shi Z, Yu M et al. Bats are natural reservoirs of SARS-like coronaviruses. Science. 2005;310:676-679.

5. Shang J, Gang Ye, Ke Shi et al. Structural basis of receptor recognition by SARS-CoV-2. Nature. 2020;581:221-24.

6. Chinese Center for Disease Control and Prevention. The Epidemiological Characteristics of an Outbreak of 2019 Novel Coronavirus Diseases (COVID-19) - China, 2020 . Available from: http://www. ourphn.org.au/wp-content/uploads/20200225-Article-COVID-19.pdf.

7. CDC. 2019 Novel Coronavirus, Wuhan, China: 2019 Novel Coronavirus (2019-nCoV) in the U.S. Centers for Disease Control and Prevention (CDC). Available at https://www.cdc.gov/ coronavirus/2019-ncov/cases-in-us.

8. European Centre for Disease Prevention and Control (ECDC). Coronavirus disease 2019 (COVID-19) pandemic: increased transmission in the EU/EEA and the UK - seventh update - 25 March 2020. Stockholm: ECDC; 2020. Available from: https://www.ecdc. europa.eu/sites/default/files/documents/RRA-seventh-updateOutbreak-of-coronavirus-disease-COVID-19.pdf.

9. Fei Zhou TY, Ronghui D, Guohui F et al. Clinical course and risk factors for mortalityof adult inpatients with COVID-19 in Wuhan, China: A retrospective cohort study. The Lancet. 2020;395:1054-62.

10. Wu Z, McGoogan JM. Characteristics of and Important Lessons From the Coronavirus Disease 2019 (COVID-19) Outbreak in China: Summary of a Report of 72,314 Cases From the Chinese Center for Disease Control and Prevention. JAMA. 2020;323(13):1239-42. mentului; nu s-au evaluat asocieri între formele clinice şi parametrii biologici.

\section{CONCLUZII}

Link-ul epidemiologic a orientat diagnosticul, în special pentru cazurile de import, focarele familiale şi colective.

Cele mai frecvente manifestări clinice ale pacienţilor cu COVID-19 internaţi în spitalul nostru au fost tusea şi febra, dar multe cazuri au fost fără febră, cu manifestări de tipul anosmie şi ageuzie.

Formele uşoare de boală au fost majoritare, formele severe au fost întânite la vârstnicii cu comorbidităţi. Decesele s-au asociat cu vârsta, HTA şi DZ.

Conflict of interest: none declared Financial support: none declared

11. Institutul National de Sanatate Publica. Distribuţia pe judeţe a cazurilor confirmate cu COVID-19 în România. Available from: https:// instnsp.maps.arcgis.com/apps/opsdashboard/index.html\#/5eced7965 95b4ee585bcdba03e30c127 -accesat 31 mai2020.

12. Centrul National de Supraveghere si Control al Bolilor Transmisibile. COVID-19 - Raport saptamanal de supraveghere. Available from: https://www.cnscbt.ro/index.php/analiza-cazuri-confirmatecovid19/1761-raport-saptamanal-episaptamana20/file -accesat 31 mai 2020

13. Decret nr. 195 din 16 martie 2020 privind instituirea stării de urgenţă pe teritoriul României, publicat în Monitorul Oficial nr. 212 din 16 martie 2020

14. Wang D, Hu B, Hu C, Zhu F, Liu X, Zhang J, Wang B et al. Clinical Characteristics of 138 Hospitalized Patients With 2019 Novel Coronavirus-Infected Pneumonia in Wuhan, China. JAMA. 2020;323(11):1061-9

15. Zhang JJ, Dong $X$, Cao $Y Y$ et al. Clinical characteristics of 140 patients infected with SARS-CoV-2 in Wuhan, China [published online ahead of print, 2020 Feb 19]. Allergy. 2020;10.1111/all.14238.

16. Guan WJ, Ni ZY, Hu Y et al. Clinical characteristics of coronavirus disease 2019 in China. N Engl J Med. 2020;382:1708-20.

17. Chen N, Zhou M, Dong X et al. Epidemiological and clinical characteristics of 99 cases of 2019 novel coronavirus pneumonia in Wuhan, China: A descriptive study. Lancet. 2020;395(10223): 507-513.

18. Wu J, Wu X, Zeng W et al. Chest CT Findings in Patients With Coronavirus Disease 2019 and Its Relationship With Clinical Features. Invest Radiol. 2020;55(5):257-261.

19. Giacomelli A, Pezzati L, Conti F et al. Self-reported olfactory and taste disorders in SARS-CoV-2 patients: A cross-sectional study [published online ahead of print, 2020 Mar 26]. Clin Infect Dis. 2020; ciaa330. 